able by sensitive laboratory tests but also easily seen by the final, less exact consumer, the laboratories include a research laundry and a research bakery. In the research laundry facilities have been installed which enable the scientist to set up every conceivable condition to duplicate domestic washing procedures for experimental purposes as well as to study all types of innovation, such as new washing machines, as they appear on the market. 'Ihe same idea is behind the range of equipment in the research bakery, where all the problems confronting the baker can be duplicated and studied, and new shortening formulæ and recipes for the bakery trade formulated.

'The back, east-west block houses the pilot plant area and the development laboratories. Approximately one-third of this two-story area is clear from floor to roof so as to accommodate the larger pilot. plant equipment. Smaller pilot-plant equipment is located under the mezzanine floor which covers the remaining two-thirds of the building. The mezzanine floor itself has offices and laboratories on both sides of a central area which is equipped with benches, fume hoods and smaller pieces of development equipment.

In these laboratories problems vary considerably in magnitude. For example, the chemist may be synthesizing previously unknown compounds to test as detergents. Simultaneously, he may be developing a new chemical process for manufacturing a detergent on a commercial scale, or developing a new formula to meet certain desired performance characteristics. $\mathrm{He}$ is, in effect, responsible for both the generation of ideas leading to new products and for the development of those ideas from the laboratory bench through the pilot plant to the factory.

In order to carry out such a programme, facilities include an area under the mezzanine floor for an engineering division development group as well as various service shops. This combination permits on-the-job construction of all new pilot plant and processing equipment. The north-south connecting block between the two east-west blocks contains various constant-temperature rooms, as well as additional product research laboratories. The building also contains, in the front east-west block, a technical library which is an extension of the main library in the Basic Research Department in the City Road laboratories. Also provided are a hospital suite and a large, pleasant dining room together with a modern kitchen.

Approximately 230 of the Research Division's staff of 300 are at work in the new building, which cost more than $£ 500,000$ to build and equip. At the present time, on the production side of Hedley's business, one person out of every five is engaged in some form of research.

\title{
HATFIELD TECHNICAL COLLEGE
}

\author{
By Dr. W. A. J. CHAPMAN \\ Principal
}

$\mathrm{H}^{\wedge}$ ATEIELD Technical College has just completed the first five years of its existence. The College is a unit in the plan for Hertfordshire which includes senior colleges at Letchworth, Hatfield and Watford, associated with a chain of colleges of further education. When the plan is complete, Hatfield will have close ties with colleges at St. Albans (4 miles), Welwyn Garden City (3 miles), Hertford ( 8 miles) and Barnet ( 8 miles), to offer a comprehensive service for the central portion of the county.

The College was conceived in 1947 to be on a ninetyacre site to the south of Hatfield presented to Hert fordshire County Council by Mr. A. S. Butler, at that time chairman of the de Havilland Company, Ltd. An interesting feature of the preliminary planning was the almost complete absence of any organized service of further education in the area upon which estimates of accommodation could be based. For many years previously the de Havilland Technical School at Astwick Manor had been providing the academic facilities for the Company's apprentices, and latterly the County Council participated in its work. The remainder of the population in the area sought their educational facilities in London, to which transport facilities are good.

The work on the building started late in 1948 and it was opened for classes in 1952 as the first completely new college erected after the War. The building is of modern design with the accommodation on a single floor except at the front where, due to a sloping site, the upper floor is on the level of the rest of the building. The construction is of a framed semi-prefabricated character with a reinforced concrete frame and brick in-filling. This form of construction was dictated by the shortage of steel prevalent at that time, and the bulk of the concrete frame members were manufactured at a plant set up a few miles from the site. The accommodation originally planned included facilities for engineering, science, building, commerce and social and professional studies; but about 1950, during the course of erection, the wing containing the science laboratories was subjected to an economy measure and became deferred. This necessitated some temporary improvization by the conversion of low-level accommodation and delayed the start of science work until January 1953.

When classes commenced, except for small numbers of A.F.R.Ae.S. students, the most senior work in operation was for the third year of the Ordinary National Certificate in engineering by a feed from the de Havilland Technical School which, by an arrangement with the Ministry of Education, was conducting S.2 classes. Engineering was conducted in the two departments of works and production and technical and design, with emphasis on manufacture and design, respectively. The electrical work was shared between these departments according to its practical or professional bias. From the beginning, all first-year work in engineering was conducted at the colleges of further education as the first stage of the Authority's plan to remove progressively all work up to intermediate standard. Work in all faculties other than engineering commenced at the first year of studies with a year's delay in any serious work in science.

The growth of the demand on the College and its expansion in numbers and staff have been considerable. The support was probably stimulated by the development of the new towns at Hatfield and Welwyn Garden City, and the increases in population 
taking place in other parts of Hertfordshire, but no doubt the main impetus was the spirited interest shown by industry.

The County Council realized that the enlightened governance of the College would be achieved only by the inclusion of a large proportion of governors representing industry, commerce and the universities, while the representatives of the County Council themselves were men and women with wide experience of the sort of problems with which the new College was likely to be faced.

In addition to the guidance given over the years by the Governing Body itself, each department set up an advisory committee consisting of representatives of the industry concerned with particular technologies. The influence of these committees has been immeasurable. Busy executives have given up their leisure time without stint, and the confidence they have shown through this work has been an inspiration to the staff of the College.

Experience in an entirely new building, devoid of any tradition and in an area lacking anything in the way of precedent, has necessitated a few adjustments during the course of development. The initial plan of the head of a department, acting as academic registrar, proved to be impracticable and the commerce and social studies were merged into one, releasing the head of the former to take the post of academic registrar. The rapid growth of electrical engineering necessitated the formation of a separate department and some internal adaptations to provide more laboratory accommodation. The formation of a science department was delayed some twelve months from the start owing to delays in providing temporary accommodation.

A new building, especially if planned on unusual lines, excites comment, and this one was no exception. Visitors have come from all parts of the world, in some instances to make a very close study of the design and layout. Those who have been in the College during these past five years have appreciated the thought that went into its design and, now that the surroundings are mellowing, its charm and suitability for its function. In some respects, it was soon found to be too small to do all that was needed, but it has lent itself readily to minor adaptations to meet the changing demands of industry. The completion in the next two years of a new block which includes mainly laboratories, classrooms and more library accommodation will give that extra space which at present is lacking.

At the end of five years the College is now established on a firm basis with a full programme of Higher National Certificate and Diploma work in engineering, building, management and chemistry and final City and Guilds courses in various subjects. The College has a part-time degree course in aeronautical and electrical engineering and sandwich courses are being developed with a view to a future application for the Hives award. The recent visiting party from the Royal Institute of Chemistry is to recommend approval of courses for Parts I and II of the A.R.I.C. examination. The arrangements being made by the Governors and the Authority, for a number of neighbouring colleges of further education, will result in all work of intermediate standard being taken out of the College within a few years. By its character and setting, together with the tradition it has already attained, the College is well set for the responsibilities that this stage will involve.

\section{MODERN ANALYTICAL CHEMISTRY IN INDUSTRY}

$\mathrm{W}$ I'I'H the increasing interest in scientific symposia and congresses one sometimes wonders wherein lies their attraction. Is it the attractiveness of the venue, the brilliance of the speakers, the interesting or topical nature of the subject-matter or is it a mere thirst for knowledge? Certainly the Congress on "Modern Analytical Chemistry in Industry", organized by the Scottish Section of the Society for Analytical Chemistry and held in the University of St. Andrews during June 24-28, had all these qualities and was an outstanding success. Three hundred delegates attended, and many more applications had to be refused. The Congress was remarkably well organized, and the organizing committee, consisting of Dr. Magnus Pyke (chairman), Mr. J. A. Eggleston (secretary), Mr. J. Brooks, Mr. H. C. Moir and Mr. A. F. Williams, had not only planned well but continued to give themselves unsparingly to ensuring the smooth running of the Congress and the comfort of the delegates.

The lectures were divided into three sections, dealing respectively with analyses in modern industry, the application of some newer analytical techniques in industry, and developments in analysis for new problems in industry. Each section was prefaced by a special lecture, the lecturers being Dr. J. Craik, chairman of the Nobel Division, Imperial Chemical Industries, Dr. E. B. Hughes, chief chemist of J. Lyons and Co., Ltd., and Prof. G. F. Smith, University of Illinois. Altogether, there were twenty-three lectures spread over eight sessions, each session being presided over by one of the following well-known personalities in chemistry: Prof. E. L. Hirst, Dr. H. W. Melville, Dr. D. Trail, Dr. R. Belcher, Prof. D. H. R. Barton, Dr. C. L. Wilson, Dr. D. W. Kent Jones and Dr. Magnus Pyke.

The Congress was opened by Dr. Magnus Pyke, who referred to the changes taking place in analytical chemistry. There was a basic change, the uncovering of the knowledge of the physical world and particularly the unfolding of the nature of atomic structure, bringing a simplicity to the understanding of the diverse elements. A second change was the increasing use of physical instruments to measure the progress of chemical reactions. While these needed to be supervised by an analyst understanding the operating principles of the instruments and the chemistry of the reactions which they interpreted or measured, their manipulation could be entrusted to a young girl. A third change came from changes in the chemical industry with its trend towards continuous operations and automatic control.

Dr. J. Craik then opened the first group of lectures with his introductory lecture on "Analytical Chemistry in Industry". He stressed the help given to analysis by new techniques and by the development of instrumentation, help in overcoming limitations of man-power and in enabling problems to be solved which could not have been undertaken by the older classical methods. For example, the analysis of glycerol had been greatly simplified and speeded up by adopting the sodium metaperiodate method. Even simple volumetric procedures such as the determination of sulph uric acid, nitric acid and nitro compounds could be improved by the use of automatic titrimeters. The use of some of the newer techniques had also stimulated research into the behaviour of existing 